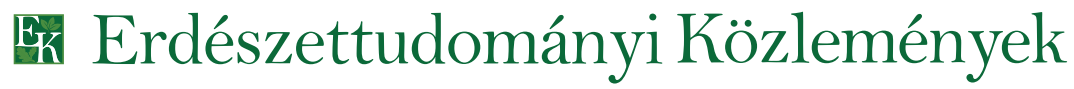

\section{FIATAL SOMOGYI KOCSÁNYTALAN TÖLGYEK ÉS CSERTÖLGYEK SZÁRAZSÁGÉRZÉKENYSÉGÉNEK ÖSSZEHASONLÍTÓ VIZSGÁLATA}

\author{
Németh Tamás Márton, Szabó Orsolya és Móricz Norbert
}

Ökológiai és Erdőművelési osztály, SOE-ERTI

\begin{abstract}
Kivonat
Jelen munkánkban somogyi kocsánytalan tölgyek és csertölgyek (Quercus petraea, Q. cerris) aszályra adott növekedési reakcióját vizsgáltuk, egy csapadék gradiens mentén. Az értékeléshez 136 évgyürümintát használtunk fel, valamint az aszályérzékenység meghatározásához dendroökológiai számításokat végeztünk. A vízhiányt a talaj vízháztartásán alapuló nedvesség-stressz index felhasználásával becsültük meg. Az eredmények alapján, mindkét fafaj évgyürü képzését leginkább az adott év nyári csapadék mennyisége határozta meg, de a két fafaj eltérő stratégiát folytat az aszályos időszakok átvészelésére. A csertölgy érzékenyebben reagált az aszályokra, mint a kocsánytalan tölgy, amely a faj aszályokkal szembeni kisebb ellenállási és nagyobb regenerálódási képességéböl adódott. A csertölgy esetén a növekedés visszaesése egyenesen arányos volt a nedvesség-stressz érték növekedésével, míg a kocsánytalan tölgy az egyre erősödő szárazságra erőteljesebb növedék visszaesést mutatott, ami a faj kisebb mértékủ rugalmasságára utal. Mindezek alapján úgy látszik, hogy a csertölgy jobban ellenáll az aszályoknak, mint a kocsánytalan tölgy, így akár versenyképesebb is lehet az elöre jelzett klímaváltozás kapcsán.
\end{abstract}

Kulcsszavak: kocsánytalan tölgy, csertölgy, dendrokronológia, aszály

\section{COMPARATIVE DROUGHT SENSITIVITY ANALYSIS OF YOUNG SESSILE OAK AND TURKEY OAK TREES IN SOMOGY COUNTY (HUNGARY)}

\begin{abstract}
This paper analyses the drought induced growth responses of oak trees, sessile oak (Quercus petraea) and Turkey oak (Q. cerris), along a precipitation gradient in Somogy County. 136 tree-ring samples were analysed and dendroecological metrics were also applied to assess the drought sensitivity of the species. Water deficit was estimated by using the soil water budget based water stress index. Results indicated a strong dependency of annual tree ring width on the water availability of current year summer but found different strategies of the two tree species against drought conditions. Turkey oak responded more sensitively to droughts than sessile oak revealed by the significantly lower resistance and higher recovery potential of this species. A linearly proportional increase of growth reduction with rising water stress was found for Turkey oak while the growth response of sessile oak decreased considerably with increasing aridity indicating lower growth plasticity of sessile oak to droughts there. Based on our findings it seems that Turkey oak copes better with droughts than sessile oak and may gain competitive advantages under the projected climate change.
\end{abstract}

Keywords: sessile oak, Turkey oak, dendrochronology, drought 


\section{BEVEZETÉS}

Az elmúlt évtizedekben egyre gyakoribbá és súlyosabbá váltak az aszályok Európában (Spinoni et al 2015), és ez a tendencia várhatóan még a jövőben is folytatódik (IPCC 2018). Ez nyilvánvalóan negatív hatással van az állományok növekedésére, ezáltal befolyásolva az állományok fatermését is (Peltier et al 2016, Mátyás et al 2018, Schuldt et al 2020). Továbbá a gyakori, hosszan tartó és rendkívüli aszályok sok esetben az erdők nagymértékủ vitalitás vesztésének közvetlen vagy közvetett meghatározó tényezői, például a másodlagos biotikus károk révén (Rasztovits et al 2014, Busotti \& Pollastrini 2017). Az ilyen folyamatok valószínűleg intenzívebbek a fafajok elterjedésének szárazsági határa mentén (Weber et al 2013), azonban a fanövekedés aszály okozta csökkenése ugyanolyan fontos lehet a faj elterjedési területén belül is (Cavin \& Jump 2017).

Európa mérsékelt övi területein élő egyes őshonos fafajok, mint például a közönséges bükk (Fagus sylvatica L.), vagy a kocsányos tölgy (Quercus robur L.) aszályra adott válaszreakciójának megértése már régóta a kutatások középpontjában áll (Scharnweber et al. 2011, Árvai et al 2018, Vanhellemont et al 2019). Viszont azokról a fafajokról, amelyekröl feltételezhető, hogy Közép-Európában jobban tolerálják az aszályt, mint például a csertölgy (Quercus cerris L.), erdei fenyő (Pinus sylvestris L.), vagy a fekete fenyő (Pinus nigra Arn.), jóval kevesebb információ áll rendelkezésünkre (Mészáros et al 2011, Misi \& Náfrádi 2017, Móricz et al 2018).

Magyarországon a kocsánytalan tölgy (Quercus petraea (Matt.) Liebl.) és a csertölgy ökológiailag és gazdaságilag is a legfontosabb fafajok közé tartozik, együttesen az összes erdőterület mintegy $21 \%$-át teszik ki. Mivel hosszú életủ és domináns fajokról van szó, mindkettőnek fontos szerepe van a szukcesszió folyamatában, hiszen fényigényesek, mély gyökérzettel rendelkeznek, és gazdag makktermésre képesek. Domb- és hegyvidéki, közepes és jó vízellátottságú talajokat kedvelnek, de akár sziklás talajokon is elöfordulnak, az alacsony pH-értékủ talajt is eltürik, továbbá mindkét fafajt Európában szárazságtürőként tartják számon (Nardini et al 1999, Härdtle et al 2013, Zimmermann et al 2015). A jövőben várható kedvezőtlen éghajlati változások miatt a csertölgyet a kocsánytalan tölgy potenciális helyettesítő fafajaként tartják számon (Führer et al 2011).

Magyarországon a tölgyerdök - elsősorban a kocsányos és kocsánytalan tölgy - vitalitása már az 1980-as években jelentős romlást mutatott az elhúzódó aszályos időszakoknak köszönhetően. A tendencia az 1990-es évek eleje óta jelentkező rendkívül száraz évek sorozatával folytatódott, melyek föként a kocsánytalan tölgy vitalitására volt negatív hatással (Mészáros et al 2008, 2011, Árvai et al 2018, Gulyás et al 2019).

A kocsánytalan tölgy (KTT) és a csertölgy (CS) aszályokra adott reakcióját ökofiziológiai szempontból kevesen vizsgálták (Mészáros et al 2011), és hasonlóan kevés számú kutatás foglalkozott dendroklimatológiai összehasonlitásukkal (Ciceu et al 2020). Mivel az éghajlatváltozás következtében szélsőségesebb és időben elhúzódó aszályok várhatók, fontos kérdés, hogy a csertölgy aszályokra adott növekedési reakciója kedvezőbb-e, mint a kocsánytalan tölgy esetében.

Jelen munkánkban a klíma és a radiális fanövekedés kapcsolatát vizsgáltuk somogyi fiatal kocsánytalan és csertölgy állományok kapcsán, egy csapadék gradiens mentén. Az összehasonlitáshoz dendrokronológiai adatokat és éghajlati mutatókat használtunk, valamint az aszályra adott növekedési reakciókat elemeztük (Lloret et al 2011, Thurm et al 2016, Schwarz et al 2020).

\section{ANYAG ÉS MÓDSZER}

\section{Vizsgálati terület}

A mintaterületeket Somogy megyében, Iharos (IH), Zselickisfalud (ZS) és Szántód (SZ) települések közelében jelöltük ki (1. ábra). A vizsgált elegyes állományok közül csak a Zselicben lévők helyezkedtek el egymástól kissé távolabbi (<600 m) erdőrészletekben (1. táblázat). Az egyes helyszínek közötti csapadékmeny- 
nyiség különbségét az 1985-2018 közötti időszakot figyelembe véve, a legnedvesebb az IH (774 mm), majd ZS $(711 \mathrm{~mm})$ és a legszárazabb SZ $(614 \mathrm{~mm})$ volt. Az összehasonlíthatóság érdekében minden állomány mageredetü, hasonló termőhelyi körülmények között, mély, alacsony váztartalmú, többletvízhatástól független agyagos barna erdőtalajon, valamint 210 és 290 m közötti tengerszint feletti magasságban helyezkedik el. Minden helyszínen domináns faegyedeket jelöltünk ki mintavételre, annak érdekében, hogy az esetleges állományszerkezeti hatásokat minimalizáljuk.

\section{Meteorológiai adatok és talajvízkészlet meghatározása}

Délnyugat-Magyarországon a hőmérséklet múltbeli változása egyértelmű felmelegedési tendenciát mutatott az elmúlt három évtizedben. A vizsgálati helyszínek éves csapadékmennyiségei közötti különbségek kissé csökkentek köszönhetően annak, hogy az iharosi területen kisebb mértékű csökkenés, míg a másik két területen növekedés volt megfigyelhető az elmúlt időszakban.

A vizsgált időszak alatti (1985-2018) klíma- és növekedésreakció elemzéséhez különböző meteorológiai adatbázisok voltak segítségünkre. A napi minimum és maximum hőmérsékleti értékek, az 1 km-es felbontású DAYMET adatbázisból származnak (Moreno \& Hasenauer 2015).

Az 1985 és 2010 közötti havi csapadék adatok a homogenizált és interpolált, 10 km-es felbontású CARPATCLIM adatbázisból származtak (Szalai et al 2013). Ezen kívül az Országos Meteorológiai Szolgálat (OMSZ) által üzemeltetett legközelebbi meteorológiai állomások csapadékadatait is felhasználtuk a 2011-2018 közötti időszakra vonatkozóan (1. ábra). A standardizált csapadék-párolgási (SPEl, Vicente Serrano et al 2010) és az erdészeti aszályossági indexeket (FAl, Führer et al 2011) a havi meteorológiai adatokból származtattuk és különböző időléptéket (havi/évszakos/évi) használva korreláltattuk a növekedéssel.

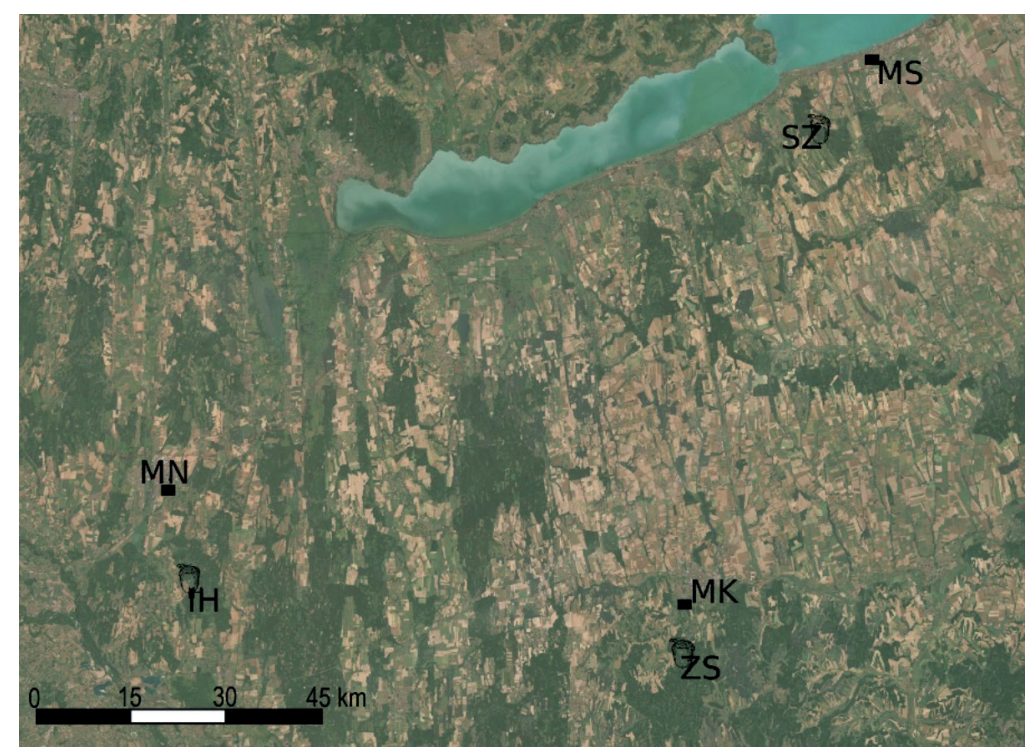

1. ábra: A mintaterületek elhelyezkedése (MN: meteorológiai állomás Nagykanizsa, MK: meteorológiai állomás Kaposvár, MS: meteorológiai állomás Siófok, IH: Iharos, ZS: Zselickisfalud, SZ: Szántód)

Figure 1: Location of the study sites (MN: meteorological station of Nagykanizsa, MK: meteorological station of Kaposvár, MS: meteorological station of Siófok, IH: Iharos, ZS: Zselickisfalud, SZ: Szántód) 
A vizsgálati időszak (1985-2018) havi vízmérlegmodelljének meghatározásához a Thornthwaite típusú modellt alkalmaztuk (Thornthwaite 1948). A modell bemeneti változóit a havi átlaghőmérséklet, a csapadékösszeg, a földrajzi szélesség és a talaj víztároló kapacitása képezi. A gyökérmélységet egységesen 1 m-re határoztuk meg minden állományban, a talajszelvényekben található hajszálgyökerek vizuális megfigyelésének segítségével. A talajmintákat minden esetben legalább három mélységből vettük. A talajok nedvesség megtartó-képesség vizsgálatához három ismétlésben 1,3 m mélységig (négy különböző szintben) bolygatatlan talajmintákat vettünk $100 \mathrm{~cm}^{3}$-es hengerrel (2. táblázat). Kiegészítésül a nyári hónapok nedvesség-stressz indexét $\left(I_{S}\right)$ is meghatároztuk, a talaj vízhiány értékét osztva a talaj felső 1 méteres mélységéből maximálisan elérhető vízmennyiség értékével (Granier et al 1999).

1. táblázat: $A$ föbb állomány jellemzők

Table 1: Main stand characteristics

\begin{tabular}{|c|c|c|c|c|c|c|c|}
\hline Helyszín & Fafaj & $\begin{array}{l}\text { Tengerszint feletti } \\
\text { magasság }(\mathrm{m})\end{array}$ & Kitettség & Kor & $\begin{array}{c}\text { Elegyarány } \\
(\%)\end{array}$ & $\begin{array}{l}\text { Magasság } \\
(\mathrm{m})\end{array}$ & $\begin{array}{c}\text { Átmérő } D_{1,3 \mathrm{~m}} \\
\mathrm{~cm})\end{array}$ \\
\hline \multirow{2}{*}{$\mathrm{IH}$} & KTT & 220 & É & 29 & 38 & 13 & 11 \\
\hline & CS & 220 & $\begin{array}{l}\dot{E} \\
\end{array}$ & 29 & 15 & 13 & 13 \\
\hline \multirow{2}{*}{ ZS } & KTT & 280 & DK & 35 & 51 & 15 & 12 \\
\hline & CS & 280 & DK & 36 & 49 & 20 & 14 \\
\hline \multirow{2}{*}{$S Z$} & KTT & 275 & NY & 33 & 13 & 15 & 16 \\
\hline & CS & 275 & NY & 33 & 67 & 16 & 14 \\
\hline
\end{tabular}

\section{Mintavétel és adatfeldolgozás}

A mintaterületek állományaiban fafajonként 12 domináns egyed került kijelölésre, majd minden faegyedből Pressler-fúró segítségével két irányból (É, K), mellmagasságban (1,3 m) vettünk növedékcsapmintát ( $\Sigma 144 \mathrm{db}$ ). A mintákat száradás, ragasztás és csiszolás után, nagy felbontásban (1200 dpi) beszkenneltük. A digitális képek feldolgozásához a WinDENDRO programot (Regent Instruments Canada Inc. 2014) használtuk, ahol az évgyürüszélesség mérése 0,001 mm-es pontossággal történt. A keresztdatálást a COFECHA (Holmes 1983) programmal hajtottuk végre. Minden potenciálisan hibás mintát újból ellenőriztünk és javítottuk, amennyiben ez lehetséges volt. Amennyiben erre nem volt lehetőség, úgy azokat kivettük a további elemzésböl, így összesen $136 \mathrm{db}$ évgyürümintával dolgoztunk. A minták trendmentesítéséhez és a további elemzésekhez az R statisztikai program dpIR csomagját használtuk (Bunn 2008). A trendmentesítésnél a simítógörbe tulajdonságán nem változtattunk, mert megfelelőnek bizonyult a viszonylag rövid évgyürü sorozataink esetében is. A trendmentesített sorozatokat az Akaike-féle információs kritérium (AIC) értékével ellenőriztük, majd a kétsúlyú robosztus átlagolással kerültek meghatározásra az évgyürüindex sorozatok. A végső index sorozatokban meglévő, a klímához illeszkedő jel megbízhatóságát a populációs jel (EPS) és a minták közötti átlagos korreláció (Rbar) értékeivel ellenőriztük. Az EPS minden sorozat esetén 30 éves ablakokban 10 éves lépésekkel került kiszámításra (Wigley et al 1984). Az elmúlt évtizedekben Somogy megyében bekövetkezett jelentősebb rovarkárok kapcsán (Hirka 2006), megvizsgáltuk azok évgyürűszélesség-növekedésre gyakorolt hatását is. Ehhez a növedék és a klíma közötti lineáris regresszió esetén Cook-féle távolságot (Cook \& Weisberg 1982) számoltunk, így meghatározva a kiugró éveket.

A regressziós elemzések változói az első esetben a fanövekedés és a nedvesség-stressz index, valamint a MODIS mủholdfelvételekből származó standardizált NDVI nyári átlaga és a nedvesség-stressz index értékei voltak (Somogyi et al 2018). Utóbbi ellenőrzés egyértelműsítette, hogy a csökkent fotoszintetikus aktivitást a rovarkárok okozták. Ezáltal a károsítással befolyásolt éveket kiszürtük így azok a további feldolgozásban már nem szerepeltek. 
2. táblázat: A mintaterületek föbb talaj jellemzöi

Table 2: Main soil characteristic of the sites

\begin{tabular}{|l|c|c|c|c|}
\hline \multicolumn{1}{|c|}{ Helyszín } & IH & \multicolumn{2}{c|}{ ZS } & SZ \\
\hline Állomány & CS-KTT & CS & KTT & CS-KTT \\
\hline Max. elérhető talajnedvesség $(\mathrm{mm} / \mathrm{m})$ & 157 & 176 & 166 & 157 \\
\hline Nedvessétartalom pF 2,5 (mm) & 33,88 & 32,4 & 32,7 & 32,33 \\
\hline Nedvessétartalom pF 4,2 (mm) & 17,65 & 13,9 & 14,4 & 14,93 \\
\hline $\mathrm{pH}\left(\mathrm{H}_{2} \mathrm{O}\right)$ & 5,16 & 6,17 & 5,99 & 5,72 \\
\hline
\end{tabular}

\section{Adatelemzés}

Mintaterületenként mindkét fafaj évgyürü-kronológiáját, a havi és adott időszak meteorológiai adatait (átlaghömérséklet és csapadékösszeg), továbbá a származtatott indexek (FAI, SPEI és I $I_{\mathrm{s}}$ ) közti kapcsolatot Pearson-féle korrelációs együtthatóval határoztuk meg. A havi korrelációs együtthatókat egy 18 hónapos - az előző év áprilisától az évgyürű kialakulási évének szeptemberéig tartó - időszakra számoltuk ki, tekintettel arra, hogy az előző év időjárása is befolyásolja a következő évi fejlődést. Ezenkivül, a 2-12 hónapos SPEI értékeket használtuk, hogy számszerűsíteni tudjuk az időjárási körülmények hatásait különböző időszakokban. Az évgyürüszélességgel legerősebb korrelációban lévő meteorológiai változó időbeli stabilitását egy 15 éves mozgó ablakos korrelációs elemzéssel ellenőriztük.

A tölgyfajok a változó éghajlati viszonyokra adott reakciójának összehasonlitását a 2001-2018 közötti időszakra vizsgáltuk, mivel ezen intervallumra minden állomány teljes évgyürü adata rendelkezésre állt. A legerősebb korrelációt mutató meteorológiai indexet összehasonlítottuk a megfelelő évgyürüértékekkel, nemparametrikus regresszió segítségével minden állományra vonatkozóan, a kapcsolat nem lineáris jellege miatt.

Az aszályos éveket a standardizált nyári nedvesség-stressz indexek segítségével határoztuk meg. Azokat az éveket tekintettük aszályos éveknek, amelyek szórás felénél nagyobb mértékben tértek el a hosszútávú átlagtól (1985-2018).

Az aszályos évekre és a többéves aszályos időszakokra az ún. Lloret-féle aszályreakciós mutatókat számoltunk ki (Lloret et al 2011). Ezek a dimenzió nélküli mutatók azt fejezik ki, hogy a fák hogyan tudják elviselni az aszályt (ellenállás - RES), miként tudnak regenerálódni (helyreállás - REC), valamint képességet az aszály előtti növekedési szint eléréséhez (rugalmasság - RESI). A többéves aszályok esetében az ellenállás és helyreállás mutatókat úgy számítottuk ki, hogy átlagoltuk az egymást követő aszályos évek értékét.

Ezenkivül két másik mutatót - a regenerációs időszak hossza (RP) és a teljes növekedéscsökkenés (TGR) - is felhasználtunk az értékeléshez (Thurm et al 2016). Az RP azt az időtartamot jelenti években kifejezve, amelynek el kell telnie ahhoz, hogy az aszályt megelőző növekedési értéket újból elérje. A TGR azt mutatja meg, hogy mekkora az aszály miatt bekövetkezett növekedéscsökkenés összege, beleértve az aszályos évet és az RP alatti növekedés veszteségét is. Mind a Lloret-, mind a Thurm-féle mutatóknál a trendmentesített kronológiák értékeivel számoltunk, mivel a nyers évgyürủ adatokat általában erősen befolyásolják a fa korából fakadó növekedésbeli eltérések (Lloret et al 2011). Kiszámításra került továbbá fafajonként, az összes aszályos időszakra mindhárom területen a TGR összege. A mintaterületek és fajok közötti különbségek értékeléséhez a TGR és az $I_{s}$ arányát használtuk, az összes aszályos évet figyelembe véve. Végül összehasonlítottuk az ellenállás és a helyreállás mutatók közötti kapcsolatot is (Schwarz et al 2020). 


\section{EREDMÉNYEK ÉS MEGVITATÁS}

\section{Évgyưrüelemzés}

A minták mérései alapján a tölgyállományok faegyedeinek kora 14 és 30 év között változott. Az EPS átlagértéke $(0,91-0,98)$ meghaladta a szigorúbb 0,90-es határértéket, így egyértelmüen kijelenthető, hogy a vizsgálat kellően reprezentatív volt. A két fafaj átlagos évgyürüszélessége között szignifikáns különbség nem adódott, azonban a helyszínek összehasonlitásakor - mindkét faj tekintetében - a zselici minták értékei határozottan magasabbak voltak $(p<0,001)$.

Fiatal egyedekről lévén szó, a fiatalkori növekedés korai éveinek hasonlóságára számítottunk, azonban ez mégis kevésbé volt megfigyelhető a minták között. A rendelkezésre álló erdöleltári adatok, valamint az első datált évgyürük alapján, a tölgy egyedek kezdő életkora 5 és 10 év között változott.

A csertölgy egyedek átlagos érzékenység (MS) értékei magasabbak voltak, de növekvő MS értékeket kaptunk mindkét tölgyfaj esetében, ha a csapadékosabb terület felöl haladtunk a szárazabb terület felé (CS: 0,29-0,42, KTT: 0,22-0,28). A csertölgy évgyürü-kronológiájában az egyes évek közötti eltérések jobban megfigyelhetök, mint a kocsánytalan tölgy esetében.

A nem-klimatikus tényezők, mint például a rovarfajok tömegszaporodása is befolyásolhatják az évgyürük növekedését, mivel kártételükkel visszavetik a fák fotoszintézisét, vagy akár súlyos lombvesztést is elöidézhetnek (Csóka \& Hirka 2009). 2005-ben mindkét tölgyfaj esetében kiugró értékeket detektáltunk a szántódi terület mintáiban. Ellenőrizve a standardizált NDVI nyári átlag, valamint nedvesség-stressz értékeket, azt állapítottuk meg, hogy a változás oka a gyapjas lepke (Lymantria dispar L.) tömegszaporodásából adódott. Habár 2006-ban megfelelő volt a talajnedvesség értéke, az előző évi kárositás hatása még érzékelhető volt a kocsánytalan tölgy évgyürü növekedésében, ezzel szemben a csertölgy növekedése esetén ennek a hatása már nem mutatkozott (2. ábra). Ezek alapján úgy döntöttünk, hogy a szántódi minták elemzésekor a 2005-ös és 2006-os éveket figyelmen kivül hagyjuk, ennek következtében a 2007-es aszályos év elemzése is kikerült az elemzésből, mivel valószínüleg a gradáció még ezt az évet is befolyásolhatta.

A meteorológiai adatok és a trendmentesített évgyürü-kronológiák közötti elemzések alapján a legmagasabb korreláció mindkét tölgyfaj esetén a tavaszi és nyári időszakokban mutatkozott. Mindkét fafaj szempontjából, a nyári csapadékmennyiség hatása pozitiv $(\mathrm{r}=0,45)$ volt, míg a nyári hőmérsékletek negatív korrelációt mutattak (CS: r= -0,49, KTT: r= -0,46). Így az előbbiek alapján elmondhatjuk, hogy az (adott év) nyári vízháztartása a legmeghatározóbb tényező a növekedés tekintetében mindkét tölgyfajunkra nézve. A legmagasabb korrelációs értékek az aktuális év nyarának nedvesség-stressz indexnél adódtak (CS: $r=-0,68, \mathrm{KTT}$ : $r=-0,66$ ), amely mutató figyelembe veszi a talajok víztartó képességét is. A nyári SPEI (CS: $r=0,45, \mathrm{KTT}: r=0,55$ ) és a FAI (CS: $r=-0,49, \mathrm{KTT}: r=-0,52$ ) mutatókkal is szoros korrelációt találtunk és a két tölgyfaj közötti korreláció nem tért el szignifikánsan egymástól.

Vanhellemont et al (2019) szerint a tölgyek esetében az előző év időjárási viszonyai nincsenek számottevő hatással a növekedésre, azonban a vizsgálatunk során szoros korrelációt találtunk az előző év őszi időjárása és a növekedés között. Érdekes viszont az, hogy az előző év nyári időjárása az esetek többségében fordított korrelációt mutatott. A csapadék gradiens tekintetében nem találtunk egyértelmü tendenciát a mintaterületek között, de a legmagasabb korrelációs együttható az iharosi terület és az adott év időjárási tényezői között volt $\left(r_{I_{H}}=0,56, r_{z s}=0,41, r_{s z}=0,49\right)$. Meglepő volt, hogy a nyári hőmérséklet hatásának erőssége a csapadékosabb iharosi területről kiindulva egyre gyengül a szárazabb, szántódi terület irányába. Azonban a 15 éves mozgóátlaggal végzett elemzés alapján, a korreláció minden állomány esetében stabil volt (SD: $0,03-0,08)$. Több kutatás szerint, a kedvező nyári vízellátottság elősegíti a szélesebb évgyürük kialakulását (Scharnweber et al 2011, Rybníček et al 2016). A nyári hőmérsékletek összehasonlításakor a június szignifikáns negatív korrelációt mutatott, az augusztusi hőmérséklet pedig csak részben volt meghatározó. Ezek alapján általánosságban 
elmondható, hogy a fiatal tölgyek különösen érzékenyek a tavaszi (az évgyürüképződés kezdetét megelőző hónapok) és a kora nyári hónapok időjárási viszonyaira, amelyet megerősítenek - idősebb állományok esetén - Európa különböző országaiban kapott eredmények (Cufar et al 2014, Rybníček et al 2016).

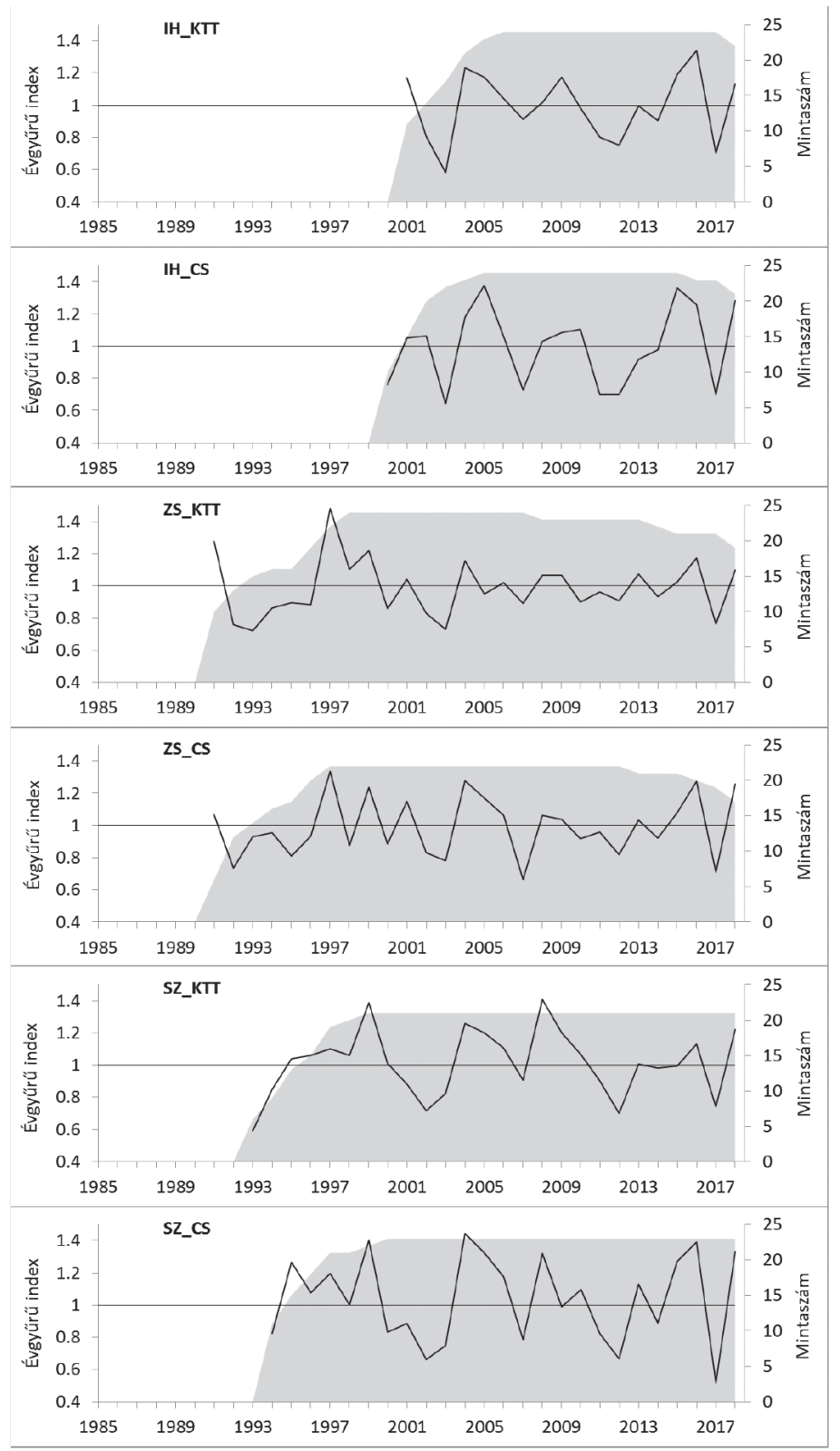

2. ábra: A vizsgált tölgyfajok trendmentesített évgyürü-kronológiája mintaterületenként Figure 2: Detrended chronologies of the oak species of the study sites 


\section{A klíma és a növekedés kapcsolata}

A csertölgy esetében azt figyeltük meg, hogy a rendelkezésre álló nedvesség mennyiségére dinamikusan válaszol azáltal, hogy az aszályos időszakokban jelentős mértékben csökkenti a növekedését, majd a következő kedvező időszakban erőteljes növedéket produkál. A kocsánytalan tölgy esetén ezzel ellentétben azt tapasztaltuk, hogy kevésbé volt érzékeny a rendelkezésre álló nedvességre. A csapadék gradienst illetően a nyári nedvesség-stressz index és a növekedés kapcsolata eltérő volt az egyes mintaterületek esetén. Habár az eltérés mértéke hasonló volt az iharosi és az szántódi helyszínen, nagyobb vízhiány esetén a növekedés visszaesése meredekebb vonalú volt a száraz szántódi állomány esetén. A zselici területen mindkét fafaj növekedésmenete kisebb mértékben volt érzékeny a változó talajvíz mennyiségére, viszont ezen a helyszínen csak egy igazán erős nyári aszályt detektáltunk. Számos szerző szerint egyes tölgy populációk a helyi klimatikus tényezőkkel szemben jól tudnak alkalmazkodni, mivel a környezeti stresszre adott adaptív válaszokat nagyrészt a genetikai sokféleség szabályozza (Clark et al 2016). Ennek oka feltételezhetően a fenotípusos plaszticitás, amely különösen megnehezíti, hogy általános következtetéseket tudjunk levonni a különböző termőhelyi feltételek között lévő tölgyállományok aszály okozta stressz hatásaival kapcsolatban.

\section{Az aszályos időszakok hatása a növekedésmenetre}

A kiértékeléshez összesen 13 aszály időszakot határoztunk meg, amelyek között egy és kétéves idöszakokat is találtunk, majd mindegyik esetében kiszámoltuk a korábban már említett Lloret-féle mutatókat (RES, REC, RESI). Az összes aszály időszakot figyelembe véve, azt az eredményt kaptuk, hogy a kocsánytalan tölgy állományok RES értéke szignifikánsan magasabb volt, mint a csertölgy állományoké ( $\mathrm{t}=-1,95$, $p<0,05)$, viszont a REC átlagértékek tekintetében pont az ellenkezője adódott $(t=3,03, p<0,05)$, így az ebből eredő RESI mindkét fafaj esetén hasonló volt (3. ábra). Az előzőeket erősíti Hoffmann et al (2018), akik szerint a nagy RES értékhez alacsony REC érték párosul, de ennek az ellenkezője is előfordulhat, ezáltal a fafajok - jellegüket tekintve - két külön csoportba sorolhatók (izohidrikus - anizohidrikus) abból a szempontból, hogy milyen módon próbálnak az aszályokkal megbirkózni (Martínez-Vilalta et al 2014, Gazol et al 2017, Mirfenderesgi et al 2019). Így a fiziológiai háttér fontos szerepet játszik, hogy az adott fafaj miként reagál a nedvesség ellátottság változásaira (Tognetti et al 1996, Mészáros et al 2011). Pretzsch et al (2012a) azt állapították meg, hogy a kocsánytalan tölgy inkább az anizohidrikus csoportba tartozik, tehát jó az ellenálló képessége az aszályokkal szemben, de az aszályok után csak lassabban tud regenerálódni. Feltételezhetöen a kocsánytalan tölgy azt a stratégiát követi, hogy az aszályok során is magas szinten tartja a párologtatását, ami a rendelkezésre álló vízmennyiség idő előtti felhasználását eredményezheti. Ezzel szemben a csertölgyek hamarabb lezárják a sztómáikat, így csökkentik a transzspirációt és a szénmegkötést. Továbbá az aszály alatt fenntartott fotoszintézis során a fáknak feltehetőleg több szénhidrát felhasználásra van szükségük, így szénhidrát tartalékuk az aszály utáni időszakra lecsökken, ami lassabb regenerációs sebességet eredményez (Michelot et al 2012). Olaszországi vizsgálatok szerint, a csertölgy a szárazsággal szembeni ellenállását a jól fejlett oldalgyökérzetének és a xilém hatékony vízszállitásának köszönheti (Tognetti et al 2007), valamint vizsgálatuk is megerősíti az általunk is észlelt aszály utáni gyorsabb növekedés megindulást.

Az elöbbieket támasztja alá Mészáros et al (2011) vizsgálata is, ahol idős cseres-tölgyes állományban a nedváramlás és a törzsnövekedés mérése azt mutatta, hogy adott aszályperiódus alatt a csertölgynél jóval nagyobb $(+38 \%)$ az átlagos nappali nedváramlás és alacsonyabb $(-42 \%)$ a törzsbeli vízdeficit értéke, mint a kocsánytalan tölgy esetén. 


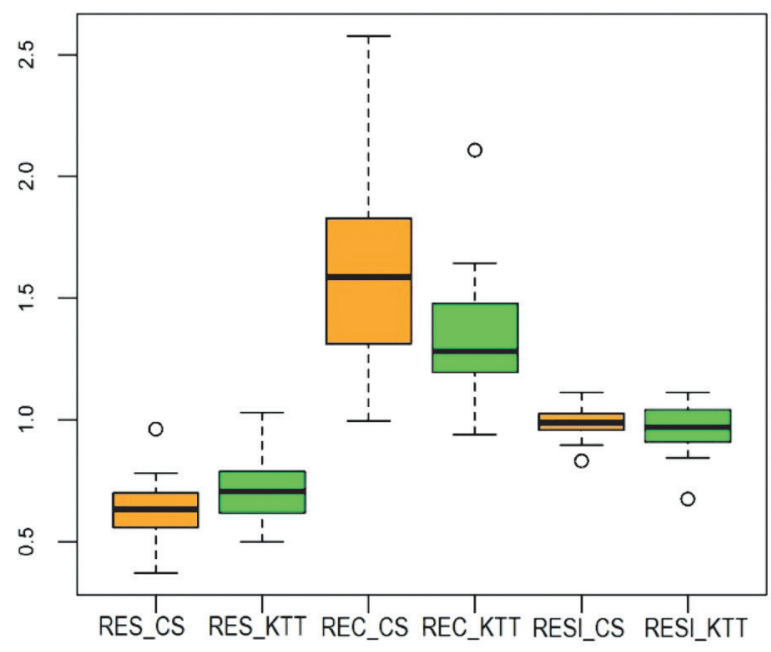

3. ábra: Lloret-féle mutatók értékei az összes aszályos időszakra ( $n=13)$ nézve (RES: ellenállás, REC: helyreállás, RESl: rugalmasság. A körök a kiugró értékeket jelzik.)

Figure 3: Graph of Lloret indices for all drought events ( $n=13, R E S$ : resistance, REC: recovery, RESI: resilience. Circles denote the outliers.)

A fentebb említett ökofiziológiai tulajdonságok és az általunk mért évgyürüszélességek alapján a csertölgy ellenálló képessége az aszállyal szemben kedvezőbb, mint a kocsánytalan tölgynél, feltehetöleg a (rendelkezésre álló) talajnedvesség takarékosabb felhasználása miatt. Habár a vizsgált fafajok fenotípusos plaszticitása és egyes környezeti tényezők meghatározó szereppel bírnak, mégis a somogyi régióban a két tölgyfaj vízfelhasználási stratégiája, valamint a (felső) talajréteg vízellátása hangsúlyosabb szerepet játszik a növekedés teljesítményében.

Ezenkívül azok a fafajok, amelyek növekedésüket aszály esetén visszafogják, mint ahogy azt a csertölgy esetében tapasztaltuk, valószínűleg az erőforrásaikat inkább a gyökerek fejlesztésére fordítják, ezzel javítva a vízhez és a tápanyagokhoz való hozzáférést. Majd az aszály elmúltával, újra helyreállhat a megszokott hajtás és gyökér növekedés egyensúlya (McCarthy \& Enquist 2007). Ezt a folyamatot figyelembe véve, a fák növekedésmenete nem tükrözi teljes mértékben az adott faegyed teljesítményét az aszály ideje alatt (Pretzsch et al 2012b). Habár a fiatalabb fák aszályreakciós válasza (RES, REC) kevésbé eltérő, mint az idősebb fáké (Candel-Pérez et al 2012), mégis vizsgálatunkban eltérő válaszreakciókat tapasztaltunk, így feltételezhető, hogy a stresszhatásra adott válaszreakció inkább fajspecifikusabb, mint korfüggő (Linares \& Tiscar 2010). Noha eredményeink arra utalnak, hogy különböző vastagsági növekedés reakcióval bírnak a vizsgált tölgyfajok aszály esetén, mégis kizárólag ez alapján nehéz lenne egyértelműen kijelenteni, hogy melyik csoportba tartozik (izohidrikus - anizohidrikus) a két fafaj. Ha a TGR értékeket hasonlítjuk össze (mindhárom területre nézve), akkor a csertölgy esetében az érték magasabb volt $(5,36)$, mint a kocsánytalan tölgyé $(5,08)$, de a különbség nem szignifikáns ( $t=0,47, p<0,05)$. A regenerációs időszak hossza (az évek száma), szinte megegyezett (CS= 21, KTT= 22).

Ennek az a lehetséges magyarázata, hogy a két fafaj hasonlóan reagál a talajnedvesség csökkenésére a jobb termőhelyeken, viszont a kocsánytalan tölgy TGR és I arányának csökkenése nagyobb sebezhetöséget (azaz érzékenységet) jelez és ezáltal gyengébb növekedésbeli plaszticitást mutat az aszályokkal szemben. A teljes rugalmasság vonalát a helyreállás, ellenállás és rugalmasság értékeinek segítségével számoltuk (4. ábra). 
A tölgyfajok RES és REC értékeit vizsgálva, azt figyeltük meg, hogy az alacsonyabb ellenállási értékekhez a csertölgy esetén magasabb helyreállási érték párosult, szemben a kocsánytalan tölggyel, és szorosan követte a teljes ellenálló képesség vonalát (Schwarz et al 2020), ami arra utal, hogy a csertölgy jobb ellenálló képességgel bír az aszályokkal szemben (ANOVA $p<0,01)$.

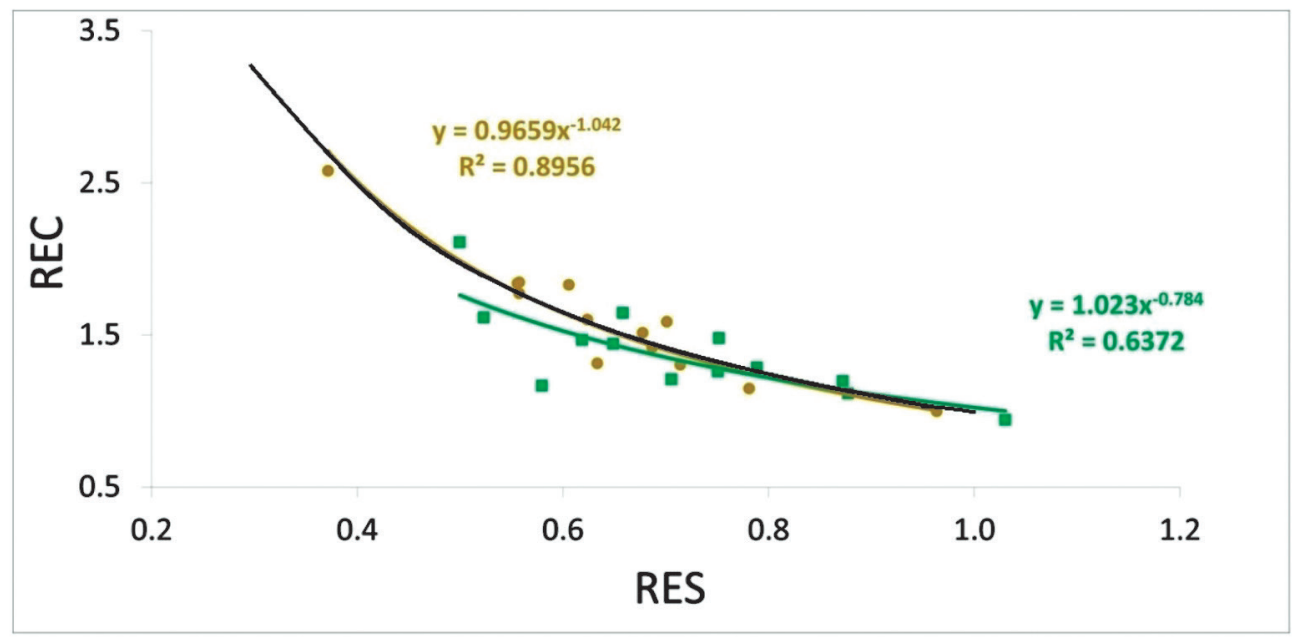

4. ábra: A KTT (zöld téglalapok és vonal) és a CS (sárga körök és vonal) ellenállás és helyreállás értékei közötti kapcsolat összehasonlitása az ún. teljes rugalmasság vonalával (fekete vonal)

Figure 4: Comparison of the relationship between resistance and recovery values for KTT (green rectangles and line) and CS (yellow circles and line) to a hypothetical line of full resilience (black line)

\section{ÖSSZEFOGLALÁS}

Fiatal kocsánytalan tölgy (Quercus petraea (Matt.) Liebl.) és csertölgy (Quercus cerris L.) állományok egyedeiböl vett növedékcsapok alapján vizsgáltuk aszályérzékenységüket egy csapadék gradiens mentén. A viszonylag rövid évgyürü-kronológiák (20-31 év) ellenére több aszályos időszak is beazonosításra került, illetve ezek hatását értékeltük a két tölgyfaj vastagsági növekedésére. Vizsgálatunkból kiderült, hogy a nyári csapadékmennyiség a fő korlátozó tényező mindkét fafaj növekedésmenetére, függetlenül a lokális klímaviszonyoktól. Az aszályos időszakokra adott válaszreakciójuk alapján azt figyeltük meg, hogy a két tölgyfaj stratégiája eltért egymástól. A csertölgy dinamikusan reagált a rendelkezésre álló nedvességre, úgy, hogy aszály idején jelentősen csökkentette növekedését, ezáltal energiát tartalékolt a túléléshez és az aszály utáni újbóli növekedés elinditásához. Ezzel szemben a kocsánytalan tölgy folyamatos növekedést mutatott az aszályok ideje alatt is, ezzel valószínüleg felhasználva tartalékainak nagy részét, és így az utána következő időszakban csak lassabb regenerációra volt képes. A kocsánytalan tölgy növekedése jelentősen csökkent az egyes vizsgálati helyszínek között, azaz a csapadék gradiens mentén, ezzel jelezve a fafaj gyengébb növekedési plaszticitását, a nedvesebb területek felöl a kedvezötlenebb termőhelyi állapotok felé haladva. Ennek következtében a kocsánytalan tölgy állományok egészségi állapota a jövőben akár jelentős mértékben is romolhat, szemben a csertölgy állományokkal, mivel elöfordulhat, hogy az egymást követő aszályos időszakok között nem lesz képes megfelelő mértékben regenerálódni. 


\section{KÖSZÖNETNYILVÁNÍTÁS}

Köszönjük a SEFAG Zrt. Iharosi, Szántódi és Zselici Erdészet munkatársainak a vizsgálataink során nyújtott segítséget. A talajelemzést ezúton is köszönjük az MTA ATK Talajtani és Agrokémiai Intézet és a SOE Erdészeti Tudományos Intézet laboratórium munkatársainak. Továbbá köszönjük Hirka Anikónak, hogy a biotikus károkkal kapcsolatban segítségünkre volt.

\section{FELHASZNÁLT IRODALOM}

Árvai M., Morgós A. \& Kern Z. 2018: Growth-climate relations and the enhancement of drought signals in Pedunculate oak (Quercus robur L.) tree-ring chronology in Eastern Hungary. IForest 11(2): 267-274. https://doi.org/10.3832/ffor2348011

Bunn A. G. 2008: A dendrochronology program library in R (dpIR). Dendrochronologia 26(2): 115-124. https://doi. org/10.1016/j.dendro.2008.01.002

Busotti F. \& Pollastrini M. 2017: Traditional and novel indicators of climate change impacts on European forest trees. Forests 8(4): 137. https://doi.org/10.3390//8040137

Candel-Pérez D., Linares J.C., Vinegla B. \& Lucas-Borja M.E. 2012: Assessing climate-growth relationships under contrasting stands of co-occurring lberian pines along an altitudinal gradient. Forest Ecology and Management 274: 48-57. https://doi.org/10.1016/j.foreco.2012.02.010

Cavin L. \& Jump A.S. 2017: Highest drought sensitivity and lowest resistance to growth suppression are found in the range core of the tree Fagus sylvatica L. not the equatorial range edge. Global Change Biology 23(1): 362-379. https://doi. org/10.1111/gcb. 13366

Ciceu A., Popa I., Leca S., Pitar D., Chivulescu S. \& Badea O. 2020: Climate change effects on tree growth from Romanian forest monitoring Level II plots. Science of the Total Environment 698: 134129. https://doi.org/10.1016/j.scitotenv.2019.134129

Clark J.S., Iverson L., Woodall C.W., Allen C.D., Bell D. M., Bragg D. C., D'Amato A.W., Davis F.W., Hersh M.H., Ibañez I., Jackson S.T., Matthews S., Pederson N., Peters M., Schwartz M.W., Waring K.M. \& Zimmermann N.E. 2016: The impacts of increasing drought on forest dynamics, structure, and biodiversity in the United States. Global Change Biology 22(7): 2329-2352. https://doi.org/10.1111/gcb.13160

Cook R.D. \& Weisberg S. 1982: Residuals and influence in regression. Chapman and Hall New York, 17-86.

Cufar K., Grabner M., Morgós A., del Castillo E.M., Merela M. \& de Luis M. 2014: Common climatic signals affecting oak tree-ring growth in SE Central Europe. Trees 28(5): 1267-1277. https://doi.org/10.1007/s00468-013-0972-z

Csóka Gy. \& Hirka A. 2009: A gyapjaslepke (Lymantria dispar L.) legutóbbi tömegszaporodása Magyarországon. Növényvédelem 45(4): 196-201.

Führer E., Horváth L., Jagodics A., Machon A. \& Szabados I. 2011: Application of a new aridity index in Hungarian forestry practice. Időjárás 115(3): 103-118.

Gazol A., Camarero J. J., Anderegg W.R.L. \& VicenteISerrano S.M. 2017: Impacts of droughts on the growth resilience of Northern Hemisphere forests. Global Ecology and Biogeography 26(2): 166-176. https://doi.org/10.1111/geb.12526

Granier A., Bréda N., Biron P. \& Villette S. 1999: A lumped water balance model to evaluate duration and intensity of drought constraints in forest stands. Ecological Modelling 116(2-3): 269-283. https://doi.org/10.1016/S0304-3800(98)00205-1

Gulyás K., Móricz N., Rasztovits E., Horváth A., Balázs P. \& Berki I. 2019: Accelerated height growth versus mortality of Quercus petraea (Matt.) Liebl. in Hungary. South-east European forestry 10(1), 1-7. https://doi.org/10.15177/ seefor.19-01

Härdtle W., Niemeyer T., Assmann T., Aulinger A., Fichtner A., Lang A., Leuschner C., Neuwirth B., Pfister L., Quante M., Ries C., Schuldt A. \& von Oheimb G. 2013: Climatic responses of tree-ring width and $\delta 13 \mathrm{C}$ signatures of ses- 
sile oak (Quercus petraea Liebl.) on soils with contrasting water supply. Plant Ecology 214(9): 1147-156. https://doi. org/10.1007/s11258-013-0239-1

Hirka A. 2006: Várható erdőkárok 2006-ban. Erdészeti Lapok 141(4): 117-119.

Hoffmann N., Schall P., Ammer C., Lede, B. \& Vor T. 2018: Drought sensitivity and stem growth variation of nine alien and native tree species on a productive forest site in Germany. Agricultural and Forest Meteorology 256-257: 431-444. https://doi.org/10.1016/j.agrformet.2018.03.008

Holmes R.L. 1983: Computer-assisted quality control in tree-ring dating and measurement. Tree-Ring Bulletin 43: 69-78.

IPCC 2018: Global warming of $1.5^{\circ} \mathrm{C}$. An IPCC Special Report on the impacts of global warming of $1.5^{\circ} \mathrm{C}$ above pre-industrial levels and related global greenhouse gas emission pathways, in the context of strengthening the global response to the threat of climate change, sustainable development, and efforts to eradicate poverty. In Press

Linares J.C. \& Tiscar P.A. 2010: Climate change impacts and vulnerability of the southern populations of Pinus nigra subsp. salzmannii. Tree Physiology 30(7): 795-806. https://doi.org/10.1093/treephys/tpq052

Lloret F., Keeling E.G. \& Sala A. 2011: Components of tree resilience: Effects of successive low-growth episodes in old ponderosa pine forests. Oikos 120(12): 1909-1920. https://doi.org/10.1111/j.1600-0706.2011.19372.x

Martínez-Vilalta J., Poyatos R., Aguadé D., Retana J. \& Mencuccini M. 2014: A new look at water transport regulation in plants. New Phytologist 204(1): 105-115. https://doi.org/10.1111/nph.12912

Mátyás Cs., Berki I., Bidló A., Csóka Gy., Czimber K., Führer E., Gálos B., Gribovszki Z., Illés G., Hirka A. \& Somogyi Z. 2018: Sustainability of forest cover under climate change on the temperate-continental xeric limits. Forests 9: 489. https://doi.org/10.3390/f9080489

McCarthy M.C. \& Enquist B.J. 2007: Consistency between an allometric approach and optimal partitioning theory in global patterns of plant biomass allocation. Functional Ecology 21(4): 713-720. https://doi.org/10.1111/j.13652435.2007.01276.x

Mészáros I., Kanalas P., Fenyvesi A., Kis J., Nyitrai B., Szőllősi E., Oláh V., Demeter Z., Lakatos Á. \& Ander I. 2011: Diurnal and seasonal changes in stem radius increment and sap flow density indicate different responses of two co-existing oak species to drought stress. Acta Silvatica et Lignaria Hungarica 7: 97-108.

Mészáros I., Veres S., Szőllősi E. Koncz P. Kanalas, P. \& Oláh V. 2008: Responses of some ecophysiological traits of Sessile oak (Quercus petraea) to drought stress and heat wave in growing season of 2003. Acta Biologica Szegediensis 52(1): 107-109.

Michelot A., Simard S., Rathgeber C., Dufrêne E. \& Damesin C. 2012: Comparing the intra-annual wood formation of three European species (Fagus sylvatica, Quercus petraea and Pinus sylvestris) as related to leaf phenology and non-structural carbohydrate dynamics. Tree Physiology 32(8): 1033-1045. https://doi.org/10.1093/treephys/tps052

Mirfenderesgi G., Matheny A.M. \& Bohrer G. 2019: Hydrodynamic trait coordination and cost-benefit trade-offs throughout the isohydric-anisohydric continuum in trees. Ecohydrology 12(1): e2041. https://doi.org/10.1002/eco.2041

Misi D. \& Náfrádi K. 2017: Growth response of Scots pine to changing climatic conditions of the last 100 years: a case study from Western Hungary. Trees 31(3): 919-928. https://doi.org/10.1007/s00468-016-1517-z

Moreno A. \& Hasenauer H. 2015: Spatial downscaling of European climate data. International Journal of Climatology 36(3): 1444-1458. https://doi.org/10.1002/joc.4436

Móricz N., Garamszegi B., Rasztovits E., Bidló A., Horváth A., Jagicza A., Illés G., Vekerdy Z., Somogyi Z. \& Gálos B. 2018 : Recent drought-induced vitality decline of Black Pine (Pinus nigra Arn.) in South-West Hungary - Is this drought-resistant species under threat by climate change? Forests 9: 414. https://doi.org/10.3390/f9070414

Nardini A., Lo Gullo M.A. \& Saelleo S. 1999: Competitive strategies for water availability in two Mediterranean Quercus species. Plant, Cell \& Environment 22(1): 109-116. https://doi.org/10.1046/j.1365-3040.1999.00382.x

Peltier D.M.P., Fell M. \& Ogle K. 2016: Legacy effects of drought in the southwestern United States: A multi-species synthesis. Ecological Monographs 86(3): 312-326. https://doi.org/10.1002/ecm.1219 
Pretzsch H., Schütze G. \& Uhl E. 2012a: Resistance of European tree species to drought stress in mixed versus pure forests: evidence of stress release by inter $\$ specific facilitation. Plant Biology 15(3): 483-495. https://doi.org/10.1111/ j.1438-8677.2012.00670.x

Pretzsch H., Uhl E., Biber P., Schutze G. \& Coates D. 2012b: Change of allometry between coarse root and shoot of Lodgepole pine (Pinus contorta Dougl. ex. Loud.) along a stress gradient in the sub-boreal forest zone of British Columbia. Scandinavian Journal of Forest Research 27(6): 532-544. https://doi.org/10.1080/02827581.2012.672583

Rasztovits E., Berk, I., Mátyás Cs., Czimber K., Pötzelsberger E. \& Móricz N. 2014: The incorporation of extreme drought events improves models for beech persistence at its distribution limit. Annals of Forest Science 71: 201-210. https:// doi.org/10.1007/s13595-013-0346-0

Regent Instruments 2014: WinDENDRO for Tree-ring Analysis. Québec, Canada Inc.

Rybníček M., Čermák P., Prokop O., Žid T., Trnka M. \& Kolář T. 2016: Oak (Quercus spp.) response to climate differs more among sites than among species in central Czech Republic. Dendrobiology 75: 55-65. https://doi.org/10.12657/ denbio.075.006

Scharnweber T., Manthey M., Criegee C., Bauwe A., Schröder C. \& Wilmking M. 2011: Drought matters - Declining precipitation influences growth of Fagus sylvatica L. and Quercus robur L. in north-eastern Germany. Forest Ecology and Management 262(6): 947-961. https://doi.org/10.1016/j.foreco.2011.05.026

Schuldt B., Buras A., Arend M., Vitasse Y., Beierkuhnlein C., Damm A., Gharun M., Grams T.E.E., Hauck M., Hajek P., Hartmann H., Hiltbrunner E., Hoch G., Holloway-Phillips M., Körner C., Larysch E., Lübbe T., Nelson D.B., Rammig A., Rigling A., Rose L., Ruehr N.K., Schumann K., Weiser F., Werner C., Wohlgemuth T., Zang C.S. \& Kahmen A. 2020: A first assessment of the impact of the extreme 2018 summer drought on Central European forests. Basic and Applied Ecology 45: 86-103. https://doi.org/10.1016/j.baae.2020.04.003

Schwarz J., Skiadaresis G., Kohler M., Kunz J., Schnabel F., Vitali V. \& Bauhus J. 2020: Quantifying growth responses of trees to drought - a critique of commonly used resilience indices and recommendations for future studies. Current Forestry Reports 6(3): 185-200. https://doi.org/10.1007/s40725-020-00119-2

Somogyi Z., Koltay A., Molnár T. \& Móricz N. 2018: Forest health monitoring system in Hungary based on MODIS products. IX. Theory meets practice in GIS. 325-330. ISBN 978 963-318-723-4

Spinoni J., Naumann G., Vogt J. \& Barbosa P. 2015: European drought climatologies and trends based on a multi-indicator approach. Global Planetary Change 127: 50-57. https://doi.org/10.1016/j.gloplacha.2015.01.012

Szalai S., Auer I., Hiebl J., Milkovich J., Radim T. Stepanek P., Zahradnicek P., Bihari Z., Lakatos M., Szentimrey T., Limanowka D., Kilar P., Cheval S., Deak Gy., Mihic D., Antolovic I., Mihajlovic V., Nejedlik P., Stastny P., Mikulova K., Nabyvanets I., Skyryk O., Krakovskaya S., Vogt J., Antofie T. \& Spinoni J. 2013: Climate of the Greater Carpathian region. Final Technical Report. URL: www.carpatclim-eu.org.

Thornthwaite C. 1948: An Approach toward a Rational Classification of Climate. Geographical Review 38(1): 55-94. https:// doi.org/10.2307/210739

Thurm E.A., Uhl E. \& Pretzsch H. 2016: Mixture reduces climate sensitivity of Douglas-fir stem growth. Forest Ecology and Management 376: 205-220. https://doi.org/10.1016/j.foreco.2016.06.020

Tognetti R., Raschi A., Béres C., Fenyvesi A. \& Ridder H.W. 1996: Comparison of sap flow, cavitation and water status of Quercus petraea and Quercus cerris trees with special reference to computer tomography. Plant, Cell and Environment 19(8): 928-938. https://doi.org/10.1111/j.1365-3040.1996.tb00457.x

Tognetti R., Cherubini P., Marchi S. \& Raschi A. 2007: Leaf traits and tree rings suggest different water-use and carbon assimilation strategies by two co-occurring Quercus species in a Mediterranean mixed-forest stand in Tuscany, Italy. Tree Physiology 27(12): 1741-1751. https://doi.org/10.1093/treephys/27.12.1741

Vanhellemont M., Sousa-Silva R., Maes S.L., van den Bulcke J., Hertzog L., De Groote S.R.E., Van Acker J., Bonte D., Martel A., Lens L. \& Verheyen K. 2019: Distinct growth responses to drought for oak and beech in temperate mixed forests. Science of the Total Environment 650(2): 3017-3026. https://doi.org/10.1016/j.scitotenv.2018.10.054 
Vicente-Serrano S. M., Beguería S. \& López-Moreno J.I. 2010: A multiscalar drought index sensitive to global warming: The standardized precipitation evapotranspiration index. Journal of Climate 23(7): 1696-1718. https://doi. org/10.1175/2009JCLI2909.1

Weber, P., Bugmann, H., Pluess, A.R., Walthert, L. \& Rigling A. 2013: Drought response and changing mean sensitivity of European beech close to the dry distribution limit. Trees: Structure and Function 27(1): 171-181. https://doi. org/10.1007/s00468-012-0786-4

Wigley T.M.L., Briffa K.R. \& Jones P.D. 1984: On the average value of correlated time series, with applications in dendroclimatology and hydrometeorology. Journal of Climate and Applied Meteorology 23(2): 201-213. https://doi. org/10.1175/1520-0450(1984)023<0201:OTAVOC>2.0.CO;2

Zimmermann J., Hauck M., Dulamsuren C. \& Leuschner C. 2015: Climate warming-related growth decline affects Fagus sylvatica, but not other broad-leaved tree species in Central European mixed forests. Ecosystems 18(4): 560-572. https://doi.org/10.1007/s10021-015-9849-x

Érkezett: 2021. október 11.

Közlésre elfogadva: 2021. november 24. 